\title{
Estimates of the Productivity Trend Using Time-Varying Parameter Techniques
}

\author{
John M. Roberts \\ Board of Governors of the Federal Reserve System \\ Stop 80 \\ Washington, D.C. 20551
}

November 2000

\begin{abstract}
In the second half of the 1990s, U.S. productivity growth moved up to rates not seen in several decades. In this paper, I use time-varying parameter techniques to isolate trend from cyclical movements in productivity and to obtain an estimate of the trend rate of productivity growth. I examine models both with and without an explicit role for capital accumulation. I find that in the models without an explicit role for capital accumulation, trend productivity growth is estimated to have moved up from around 1-1/2 percent in the period from the early 1970 s to the mid 1990 s, to about 2$1 / 2$ percent by the final observation used in this paper, the second quarter of 2000 . I find that if I allow for an explicit role for capital accumulation, the recent pace of trend productivity growth is even higher, at around 3 percent.
\end{abstract}

The views expressed in this paper are those of the author and do not necessarily reflect the views of the Board of Governors of the Federal Reserve System or any other member of its staff. I am grateful to Dan Sichel, Bill Wascher, Spencer Krane, Bruce Fallick, Charles Fleischman, and Jeremy Rudd for helpful discussions, and to Ken Kuttner for providing his computer programs. 
In the latter half of the 1990s, hourly productivity grew considerably faster than its average pace over the preceding twenty-five years. An obvious question is how much of this faster productivity growth we can expect to continue.

In addressing this question, it is helpful to make two distinctions. One is between trend and cyclical changes in productivity. Changes in trend are, by definition, permanent, whereas cyclical movements in productivity are transitory. Clearly, only the permanent part of increases in productivity will have lasting implications. Another distinction concerns how much of the increase in the trend component of productivity is the result of a one-time increase and how much reflects an increase in the growth rate of trend productivity. This distinction is important because one-time increases in trend productivity won't necessarily be repeated, whereas increases in the growth rate of trend productivity can be expected to continue.

In this paper, I use a framework in which the trend components of economic variables such as productivity are subject to random shocks, just as are the "cyclical" components. In the language of time-series econometrics, I allow the trend to follow a random walk with drift. To determine how much of the change in the trend portion of productivity implies a permanent change in the growth rate, I allow both the level and the growth rate of trend productivity to be subject to random shocks. (In time-series lingo, the drift term is also allowed to follow a random walk.)

A frequently used alternative approach to modeling trend components is to assume that they follow simple functions of time - for example, by using linear time trends, possibly allowing for breaks. Historically, these two approaches to modeling trends both do a good job of fitting the data, and so it is difficult to distinguish between 
them statistically. Prior economic reasoning also provides little basis for choosing between these approaches: Technical innovation - one of the main sources of productivity movements - might be subject to occasional jumps, as the random-shocks approach allows, if for example, there is a sudden burst (or dearth) of new ideas. On the other hand, if ideas diffuse gradually and if practical experience is accumulated only slowly, then innovation might be an inherently smooth process, as the time-trend approach assumes.

There are, nonetheless, practical reasons why the stochastic approach to modeling trends can be a useful alternative to the simpler procedure of using broken time trends. In particular, the random-shocks approach allows the trend to change each period, to whatever degree is suggested by the data. By contrast, an approach that relies on broken linear time trends can only periodically allow for a break in the trend; otherwise, there is a danger that the trend may track the actual data too closely. Thus, a practical advantage to allowing the trend to be affected by random shocks is that it is more flexible than a broken time-trend approach, allowing for continuous, incremental, and potentially more timely updating of the trend.

As I will discuss in more detail in the next section, a number of authors have looked at the properties of aggregate output using a "trend and cycle" framework. I build on this framework by including data on hours in the model as well as productivity. Hence, my approach can be thought of as in effect splitting output into its hours and output-per-hour, or productivity, components.

The results suggest two interesting observations about the cyclical properties of productivity. First, while the results confirm the well-known finding that productivity is "procyclical," in the sense that it increases when output increases, productivity 
adjusts much more rapidly back to trend than does overall output (it is therefore the hours component of output that accounts for most of the cyclical fluctuations in output). Relatedly, cycles in productivity are much shorter than the overall business cycle. As a consequence, a much larger portion of movements in productivity reflect trend movements than is the case for overall output.

An implication of the finding that productivity reverts quickly to trend is that most of the increase in labor productivity in the late 1990s reflects a rise in trend productivity. Because increases in trend are permanent, the level of productivity can be expected to stay permanently higher. The estimates also suggest that the growth rate of trend productivity has increased. As of the second quarter of 2000, my results imply an increase in the trend rate of productivity growth, to a bit more than $2-1 / 2$ percent, which marks a pick-up of more than a percentage point from the average pace of productivity growth from the early 1970 s to the early 1990 s.

Oliner and Sichel (2000) argue that capital accumulation has played an important role in accounting for the pick-up in labor productivity growth. To take account of this possibility, I consider an extended version of the model that allows capital accumulation to affect productivity growth. The random-shocks approach is then applied only to the part of productivity growth that is not explained by capital accumulation - often referred to as multifactor productivity. The results from this approach suggest a somewhat faster rate of trend productivity growth as of early 2000 than the procedure that uses only information on output per hour. In particular, if capital accumulation were to remain at its 1999 pace, this version of the model would predict that trend productivity growth was a bit more than 3 percent as of the second quarter of 2000, an even more marked step-up in the rate of trend productivity growth 
than was suggested by the model that did not account separately for the contribution of capital spending.

The paper is organized as follows: In section 1, I discuss the relationship of the approach I use in this paper to earlier research. Section 2 describes the model used in this paper; section 3 discusses the econometric techniques; and section 4 presents estimates of the parameters of the model. In section 5, I present the model's implications for the output gap and trend productivity growth. In section 6, I extend the model to allow for a separate role for the capital stock to contribute to productivity growth, and thus estimate trend multifactor productivity growth. Section 7 concludes.

\section{Relationship to earlier work}

My approach builds on work in several areas, mostly in time-series econometrics. A number of papers have modeled aggregate output as composed of a cyclical component plus a trend that can be modeled as a time-varying parameter. Examples of papers that have taken this approach using aggregate output include Watson (1986) and Clark (1986).

Kuttner (1994) used additional information to identify separately the trend and cyclical portions of output. He noted that in the traditional Phillips curve relationship, the cyclical portion of output is likely to help predict inflation. Thus, adding inflation to the model will provide additional information that may permit a better distinction between trend and cyclical movements in output.

The papers of Watson, Clark, and Kuttner all assumed that while the trend component of output can have permanent shocks to its level, the rate of trend growth is a constant. The recent experience, and that of the early 1970s, suggests, however, that the trend rate of growth may vary over time. However, these variations in trend growth 
rates are likely small relative to the overall variation in the series, and, as a consequence, it can be difficult to discern them in the data. The econometric difficulties caused by this phenomenon have been referred to as the "pile-up" problem. To help circumvent the pile-up problem posed by relatively small changes in trend growth rates, I use a technique recently introduced by Stock and Watson (1998).

The papers mentioned so far have looked only at trend output. In this paper, I am interested in identifying the trend in productivity. I look both at simple labor productivity-defined as the ratio of output to hours worked-and also at multifactor productivity. For simple labor productivity, I assume that both productivity and hours have trend and cyclical components. With all of the variables in logs, the trend in output is the sum of the trends in productivity and hours, and similarly, the cyclical portion of output is the sum of the cyclical portions of hours and productivity.

In earlier work such as Watson, Clark, and Kuttner, the cyclical portion of output was modeled as a simple autoregressive process. In a model with hours as well as output, however, it seems appropriate to consider interactions between the two variables, as suggested, for example, by the work of Braun (1990).

As noted above, Kuttner (1994) added a Phillips curve relationship to his model to allow better identification of the cyclical portion of output. In this paper, I consider models both with and without a Phillips curve relationship. I find that while including a Phillips curve helps identify the cyclical portion of output, the implications of the model are not substantially different if the Phillips curve is omitted.

Recently, Brainard and Perry (1999) have also used time-varying parameter techniques to estimate trend productivity growth. The relationship between their work and the model of this paper will be discussed in section 3 , below. 


\section{The model}

As is common in discussions of time-varying-parameter models, I will describe my model in a "state-space" framework. The variables I model are productivity and hours (in the nonfarm business sector), and, when I include a Phillips curve in my model, inflation. In the state-space framework, these are referred to as the "observation" variables. The framework's "states" are the unobserved variables that are part of the model-for example, the productivity trend and the output gap. Estimation of the model will allow these unobserved components to be uncovered.

\section{2.a. Some identities}

Output can usefully be split into hours and output per hour:

$$
q_{t}=h_{t}+\mathrm{B}_{t} \text {, }
$$

with all variables in logs. (I divide both hours and output by the civilian working-age population, and so both hours and output are per capita. Also, all log quantities are multiplied by one hundred, so that small changes in them are approximately equal to percentage changes.) Each of these components can in turn be divided into a "trend" and a "gap" component:

$$
\begin{aligned}
& h_{t}=h_{t}^{*}+\text { gapp }_{t} \\
& \mathrm{~B}_{t}=\mathrm{B}_{t}^{*}+\mathrm{Bgap}_{t} .
\end{aligned}
$$

Note that while hours and productivity are observable, the trend and gap components are not. Trend output and the output gap are then defined as:

$$
\begin{aligned}
& q_{t}^{*}=h_{t}^{*}+\mathrm{B}_{t}^{*} \\
& \operatorname{qgap}_{t}=\operatorname{hgap}_{t}+\mathrm{Bgap} .
\end{aligned}
$$




\section{2.b. Long-run properties}

Trend hours and trend productivity are assumed to follow random walks with drift:

$$
\begin{aligned}
& h_{t}^{*}={ }^{*}+h_{t-1}{ }^{*}+, 1 t \\
& \mathrm{~B}_{\mathrm{t}}^{*}=\left({ }_{t}+\mathrm{B}_{t-1}{ }^{*}+, 2 t .\right.
\end{aligned}
$$

Thus, ${ }_{2 t}$ is the shock to the level of trend productivity and ${ }_{1 t}$ is the shock to the level of trend hours. Note that they combine to form the shock to the level of potential output.

In addition, the drift term in trend productivity is itself assumed to be a timevarying parameter:

$$
C_{t}=C_{t-1}+\mathrm{L}_{t}
$$

Thus, $\mathrm{L}_{t}$ is the shock to the growth rate of trend productivity.

In the full-information maximum-likelihood estimation approach that I take, the standard errors of the shocks to the levels of trend hours and productivity are structural parameters of the model, as are the drift term in the hours equation and the standard error of the shock to the trend productivity growth rate.

In most of the estimation, I assume that the shocks to trend hours and trend productivity are unrelated. It might be reasonable to suppose, however, that a permanent increase in productivity could lead to a permanent change in hours worked. I examine this possibility in the empirical work presented below.

\section{2.c. Cyclical assumptions}

I assume that the output gap summarizes the business cycle, and that its dynamics are well captured as a simple autoregressive process:

$$
\operatorname{qgap}_{t}=\mathrm{N}_{1} \operatorname{qgap}_{t-1}+\mathrm{N}_{2} \operatorname{qgap}_{t-2}+u_{l t} .
$$


In the empirical work in section 4, I test whether the lagged hours gap has an independent role in the output gap equation. I find that it does not.

I also explored using the "hours gap" (hgap) as the cyclical variable. The results were in many respects similar. However, I found that in this alternative framework, the output gap helped explain the hours gap. From a narrow econometric perspective, this result suggests that the output gap is better approximated by a simple autoregressive process than is the hours gap. An economic interpretation of this result is that the output gap does a better job of representing the business cycle than does the hours gap.

\section{2.d. Hours model}

I look at several specifications for the hours gap. I begin with a general specification that relates the hours gap to the current and lagged output gap and the lagged hours gap:

$$
\operatorname{hap}_{t}=2_{0} \operatorname{qgap}_{t}+2_{1} \operatorname{qgap}_{t-1}+2_{2} \operatorname{hgap}_{t-1}+u_{2 t}
$$

A common assumption about hours is that they adjust gradually to output following a cyclical shock, an assumption which implies a more-restricted version of the hours equation. In this version of the model, an output shock leads initially to a lessthan-complete movement in hours, and then hours gradually "catch up" to output. One way to capture the catch-up idea is to include the lagged productivity gap in the model, with the implication that when the level of productivity is high following a shock to output, subsequent hours growth will be boosted, until the productivity gap returns to zero.

The model with these restrictions is:

$$
\text { ) } \left.\operatorname{gap}_{t}=:_{0}\right) \operatorname{qgap}_{t}+:_{1} \mathrm{Bgap}_{t-1}+u_{2 t}
$$


with $:{ }_{0}<1$ and $:{ }_{1}>0$. This partial-adjustment model is related to the more-general model through the following relationships:

$$
\begin{aligned}
2_{0} & =:_{0}, \\
2_{1} & =:_{1}-:_{0}, \\
\text { and } \quad 2_{2} & =1-:_{1},
\end{aligned}
$$

which imply the restriction:

$$
2_{0}+2_{1}+2_{2}=1
$$

In my empirical work, I begin with the more-general model and test to see whether the partial-adjustment model fits the data.

\section{2.e. The Phillips curve}

Kuttner (1994) added a Phillips curve to a univariate time-varying parameter model for output to help further identify the split between trend and cycle. The Phillips curve I use is:

$$
\text { ) } \left.p_{t}=\mathrm{E}{ }_{i}\right) p_{t-i}+\$ q g a p_{t}+\mathrm{T} X_{t}+0_{t} \text {, }
$$

where ) $p_{t}$ is inflation as measured by the price index for personal consumption expenditures, excluding food and energy, at an annual rate. The model uses ten lags of inflation. The coefficients on lagged inflation are restricted to sum to one and the last nine lags are all restricted to have the same effect, in order to further reduce the number of degrees of freedom; the data do not reject these restrictions. $X$ is a vector of supply shocks. As possible supply shocks, I considered the relative prices of food, energy, and imports. However, there is a high degree of multicollinearity among these variables, and the specification I chose includes only the relative prices of food and imports. The model also includes a wage-and-price-control dummy. 


\section{Estimation techniques}

I use a maximum likelihood method for estimating state-space models of trends and cycles that was introduced by Kuttner (1994). In broad terms, the process can be thought of as first estimating the parameters of the model, including the variances of the shocks that drive these unobserved components, and then using these parameters to estimate the movements of these unobserved components. However, the actual estimation procedure involves iterating between these two steps.

The model I estimate consists of the identities in section 2; the equations describing the trend movements in hours and productivity; the equation for the cyclical movements in the output gap; the Phillips curve; and one of the hours-adjustment equations described in section 2 . The estimated parameters include not only the standard coefficients on the variables such as appear in the Phillips curve and hours and output equations, but also the standard errors of the shocks to the level of trend hours and productivity, and the standard error of the shock to the productivity trend growth rate. The standard errors of the shocks to the trend terms are key to splitting hours and productivity into trend and gap components. Intuitively, the larger the standard error of the trend shock, the greater will be the variability of the trend, and thus the more likely that any given movement in the data will be construed as a shift in the trend, rather than a change in the gap. ${ }^{1}$

While maximum-likelihood is used to estimate most of the parameters of the model, for one parameter - the standard error of the shock to the change in the

1. I do not model the supply-shift variables shocks that enter the price equation, which makes the approach a "limited-information" variant of maximum-likelihood. As long as these supply-shift variables are not strongly affected by the other variables in the model, the estimates of the model will be econometrically consistent. 
productivity trend - earlier work suggests that maximum-likelihood techniques are inappropriate. The reasons are discussed in Stock and Watson (1998). Briefly, the idea is that if a variable has large shocks to its level, but only small shocks to its change, standard maximum-likelihood methods will tend to find that the standard error of the shocks to the change is zero, even when that is not the case. In the present case, this argument would imply that, using standard techniques, estimates of the variability of the growth rate of productivity would be biased toward zero.

Stock and Watson propose a technique, called the median unbiased estimator, which they show does a better job of capturing the true size of small shocks to the trend growth rate than does maximum likelihood. The idea behind their estimator is that if there is a shock to the trend growth rate, then if one were to run a test looking for structural stability in the growth rate, that test will tend to reject the hypothesis of structural stability. Furthermore, the larger the variance of the shock to the growth rate relative to the shock to the level, the stronger ought to be the evidence in favor of rejection of structural stability. For using this idea in practice, Stock and Watson provide a table for mapping from the results on a structural break to the size of standard error of the growth rate shock.

Stock and Watson propose estimating the standard error of the trend growth rate shock using actual growth. However, an alternative procedure that is consistent with their approach would be to estimate the structural time-varying parameter model assuming a constant trend productivity growth rate and then apply the technique to the resulting estimate of the productivity trend. In large samples, both approaches should give the same answer, although, in practice, they may differ. In my empirical work, I try both approaches. 
In a recent paper, Brainard and Perry (1999) also use a state-space modeling approach to estimate the trend productivity growth rate. Their approach differs in several respects from the approach I take here. First, they do not embed their model of productivity within a broader business cycle model. Rather, they use current and lagged values of the unemployment rate as an exogenous cyclical variable.

Furthermore, they do not use an explicit maximum-likelihood estimation framework. Instead, they search over various parameter values and choose the parameters that minimize one-step-ahead forecast errors from their model, an approach which may, in practice, be similar to a maximum likelihood approach, particularly given the simplicity of their model. To the extent that their method resembles maximum likelihood, it will encounter the same problems with small standard deviations in the change in trend growth rates that maximum-likelihood procedures confront, namely, that the estimates are biased toward zero. The possibility of bias from this source is a potential problem with Brainard and Perry's approach that they do not discuss.

\section{Parameter estimates}

\section{4.a. Model estimates with fixed trend productivity growth}

I initially present estimates of the model assuming that the trend productivity growth rate is fixed-that is, that the standard error of the shock to the productivity trend growth rate, < is zero, and thus that the growth rate itself, (, is fixed. I do this for two reasons. First, as mentioned in the previous section, one of the ways I estimate the standard error of the shocks to the productivity trend drift term is to use the productivity trend estimate from the model that first holds the drift term fixed. Also, because the standard error of the drift term is likely to be small, setting it to zero in the first stage of the estimation is not likely to affect the parameter estimates much, suggesting that 
experiments exploring sensitivity to specification changes can safely be done on the simpler version of the model. Note, however, that using a fixed trend growth rate does not mean that the productivity trend does not vary: There are still shocks to the level of trend productivity, and, given the structure of the model, these shocks have a permanent effect on the level of trend productivity.

Table 1 shows estimates of the parameters of the model with fixed trend productivity growth. The model is estimated using quarterly data from 1960:Q4 to 2000:Q2. As noted in section 3, in addition to the estimated coefficients on variables, the standard errors of the trend terms are also key structural parameters of the model, chiefly because they help determine, for example, how much the productivity trend varies. Column 1 shows estimates of the base model, which includes the unrestricted version of the hours equation. With one exception, the estimates accord with prior expectations. The exception is the standard error associated with the shock to the hours equation, which is estimated to be zero. It is perhaps odd to think of an equation lacking an error term, but recall that in this model, there are more error terms than equations, so one of the other error terms-for example, the shock to the level of trend productivity-may be picking up the noise in this equation. In the specifications that follow, this standard error is estimated to be nonzero.

The output gap equation has the typical autoregressive pattern for a cyclical driving variable, with the coefficient on the first lag greater than one, but the sum of the coefficients on the two lags less than one. In the hours adjustment equation, the coefficients on contemporary output and lagged hours are positive, as expected. The sum of the coefficients is 0.96 , which is not far from one, the value predicted by the partialadjustment-of-hours interpretation of this relationship discussed in section 2. Finally, the 
Phillips curve coefficient estimates are as expected; notably, the coefficient on the output gap is positive and statistically significant.

In column 2, I impose the restriction that the sum of coefficients in the hours model is one. As can be seen by comparing the log-likelihoods of the two models, the fit is about the same with this restriction imposed; furthermore, the other parameters of the model are little changed.

In the estimates in column 2, the coefficient on the lagged output gap in the hours equation is almost exactly zero. In developing his partial adjustment model, Braun (1990) argues that this coefficient should be zero, and he presents evidence to support this conclusion. Because this restriction is so clearly accepted by the data, it seems worthwhile imposing this restriction, which is done in column 3. Given how closely the restriction held in column 2 , it is not surprising that the coefficient estimates are little changed by imposing this restriction.

The point estimates for the hours adjustment equation in column 3 have the interpretation that hours initially respond about half as much as output to a cyclical shock, thus leading to an increase in productivity. They also imply that about half the deviation of productivity from trend is closed each quarter. This speed of adjustment is very rapid; by contrast, the output gap equation suggests that the gap only closes by about 6 percent per quarter. These results underscore that it is an oversimplification to state that "productivity is a procyclical variable:" While it is true that a cyclical shock affects productivity, productivity returns to trend long before output does, implying that most of the persistence in the cyclical portion of output stems from deviations of hours from trend. 
It is also worth noting in this regard that the standard error of the hoursadjustment model is very small. As noted above, because there are more structural error terms than observed variables in this model, such a result does not mean that the hoursadjustment model fits nearly exactly. One interpretation of the small equation standard error is that movements in productivity that are not explained by the hours adjustment model are largely captured by changes in trend productivity. Coupled with the rapid adjustment of productivity to its trend level, this interpretation implies that a substantial portion of the quarter-to-quarter variation in productivity is the result of movements in its trend. This interpretation will be manifest in the next section, where I show the levels of actual and trend productivity implied by this model.

The coefficients describing the trend components of the model are grouped under the "Trend parameters" section of table 1. In the model in column 3, the drift term in the hours equation is slightly positive but not statistically significant, suggesting only a small average increase in hours worked per person over this period. By contrast, the productivity drift term is large and significant, and suggests that trend productivity growth averaged 2.1 percent per year over the 1960-to-2000 period. The standard errors of the shocks to the trend levels of hours and productivity are both highly statistically significant, which implies that there is strong evidence in favor of permanent shocks to the levels of trend productivity and potential GDP. This result is similar to those of others who have looked at models that allow for random-walk trends, such as Kuttner (1994). The standard errors suggest that the productivity trend is about twice as variable as the hours-per-person trend.

Columns 4 and 5 present results that compare the hours gap and the output gap as summary measures of the state of the business cycle. In column 4, I add two lags of the 
hours gap to the output gap equation; otherwise, the model is the same as in column 3. The coefficients on both lags are small and not statistically significant, and the log likelihood of the model is little changed. Apparently, the hours gap does not help predict the output gap, suggesting that the output gap adequately summarizes the cycle.

In column 5, I add the hours gap to the Phillips curve of the model in column 3. As can be seen, neither the hours gap nor the output gap is statistically significant at the 5 percent level in this specification, and the overall fit of the model is little changed, although the results suggest a slight edge to the hours gap in the Phillips curve, as its coefficient remains positive. On balance, however, these results suggest that there is little to choose between the two measures with respect to the Phillips curve, probably because, with rapid adjustment of productivity to its trend level, the two cyclical measures move closely together and so serve about equally well in the Phillips curve.

In addition to the tests indicated in the table, I also explored whether there was a long-run response of labor supply to productivity shocks. To test for such an effect, I explored whether the trend productivity shock was correlated with the trend hours shock. Using the model in column 3 , the estimated coefficient on the effect of the trend productivity shock on the trend hours shock was -0.16 , suggesting that a permanent increase in productivity - and thus, implicitly, in real wages - leads to a reduction in long-run hours worked. However, the $t$-statistic on this coefficient was only 0.8 , suggesting that the effect is not statistically important, and hence that the restriction to zero in the base model is not at variance with the data.

\section{4.b. Allowing the trend productivity growth rate to change}

In the estimation so far, I have assumed that the trend productivity growth rate is constant; in particular, in the estimates in table 1, the fixed trend productivity growth rate 
was estimated to be about 2 percent per year. I next generalize the model to allow the trend productivity growth rate to be a time-varying parameter; in terms of the model in section 2, I now allow the standard error of the shock to the trend productivity growth rate, $<$ to be nonzero.

As noted in section 3, a straightforward extension of the maximum-likelihood technique that we have used so far will likely yield an estimate of the degree of the variability of the trend productivity growth rate that is biased downward. I therefore use the alternative technique proposed by Stock and Watson (1998).

Stock and Watson recommend "prewhitening" a growth rate variable by regressing it on several lags before running the trend break tests in their procedure. In the case of the productivity trend series from the model, this procedure is unnecessary, because the model procedure produces a random-walk trend. A pre-test regression also proved unnecessary for the raw productivity growth data as well, however, because these growth rates have little serial correlation.

When I apply the Stock-Watson method to the raw productivity growth data, I obtain an estimated standard error of the change in trend productivity growth of 0.22 percentage point. $^{2}$ (Note that this standard error applies to the annualized percent change in trend productivity.) As noted in section 3, an alternative approach is to apply the method to trend productivity estimated from the model; this approach amounts to using the model to remove the cyclical component of productivity before applying the technique. Using the estimates from column 3 of table 1, I obtain an estimated standard error of 0.21 percentage point, very close to the value using the raw data.

2. I use the "exponential mean" variant of the median unbiased estimator. 
Using Monte Carlo simulations, I found that this value for the standard error of the change in the trend productivity growth rate is significantly different from zero at the 10 percent confidence level, but not at the 5 percent level. ${ }^{3}$ These results are in contrast to those of Stock and Watson (1998), who examine the trend growth rate of U.S. per capita GDP using the median unbiased method. They find a range of point estimates for the standard error of the change in the trend productivity growth rate, the largest of which is 0.13 percentage point. Furthermore, their estimate is not significantly different from zero at the 10 percent confidence level. One reason for the contrasting results may be that because a higher proportion of movements in productivity are the result of changes in trend than is the case for per capita GDP, trend productivity can be estimated with more precision than trend GDP.

The upper bound of the 90 percent confidence interval of the median unbiased test statistic implies a standard error of the change in the trend productivity growth rate of 0.57 percentage point, two-and-a-half times the point estimate, reflecting the skewed nature of the distribution of the estimator. I will use this estimate below as part of my sensitivity analysis.

Table 2 shows the model's estimated parameters using the imposed trend productivity growth standard error. In other particulars, I use the same specification as in column 3 of table 1, that is, I include the restricted version of the hours adjustment model; the results from table 1, column 3 are duplicated in the third column of table 2.

3. In my Monte Carlo simulation, I used the empirical estimates of the standard errors of the labor productivity growth and of the change in trend labor productivity growth to generate simulated data, assuming that the growth rates were not serially correlated. I used 10,000 simulated series to obtain a distribution of the exponential mean test statistics, which I then converted to estimates of the standard error of the change in trend productivity growth using Stock and Watson's (1998) look-up table. 
In column 1, I use the preferred estimate of the standard error of the change in the trend growth rate, 0.22 percentage point. As can be seen, the parameter estimates change little when the trend productivity growth rate is allowed to be time-varying. (That isn't too surprising, because the standard error of the change in trend productivity growth is not very far from zero, the value used in table 1.)

I also estimated the model using maximum likelihood techniques on all the parameters of the model, including the standard error of the change in trend productivity growth. As expected, the estimate was smaller than using the Stock-Watson procedure only 0.1 percentage point. Because we would expect this estimate to be biased downward, I do not report the results consistent with it.

Column 2 shows estimates of the model assuming that the standard error of the change in the trend productivity growth rate is 0.57 percentage points, the value that is at the upper end of a 90 percent confidence interval of the median unbiased estimator. Once again, the estimated parameters of the model are little changed; as we will see in the next section, however, variation in the standard error of the change in the trend productivity growth rate has a large impact on recent estimates of trend productivity growth.

In column 4, I repeat the estimates of the model with my base estimate of standard error of the change in the trend productivity growth rate, this time deleting the Phillips curve from the model. The broad contour of the results is similar to those that include a Phillips curve. However, there are some differences. Notably, the standard errors of the trend shocks are somewhat smaller than when the model includes the Phillips curve, while the standard errors of the cyclical shock and the shock to the hours model are larger. This finding is similar to that of Kuttner (1994), who found that the 
standard error of the shock to trend output was larger in a model that included a Phillips curve.

In addition to having a larger standard error, the output gap equation also implies more serial persistence in the model that does not include the Phillips curve: The largest root is 0.97 , compared with 0.93 in when the Phillips curve is included. These results suggest that including the Phillips curve does in fact help distinguish trend from cycle, leading to a cyclical portion of output that is less persistent and thus less closely resembles the trend portion.

\section{Implications of the model for trends and cycles}

In this section, I show the implications of the model for trends and "gaps" in hours, output, and productivity. I focus on the results assuming that the standard error of the change in trend productivity growth is 0.22 percentage point, although, as a way of illustrating the sensitivity of the results to extreme assumptions about the parameters, I also show some results from the model estimated with a standard error of 0.57 .

Figure 1 shows the model's estimates of the hours gap and the productivity gap. The hours gap has the expected cyclical pattern, plunging in recession periods such as 1973-74, 1980-81, and 1990, and rising to high levels near cyclical peaks, as in the latter

years of the 1960s, 1970s, and 1980s. Consistent with the model results discussed above, the productivity gap closes much more rapidly than the hours gap, illustrating the shortcomings of the simple formulation that "productivity is procyclical:" While it is true that productivity rises in recoveries and falls in recessions, because it returns to trend much more rapidly than does hours, it is not true, for example, that whenever employment is above trend, productivity is also above trend. Until the end of the late 1990s, the productivity gap was small; with the economy's very rapid growth at the end 
of 1999 and in early 2000, a gap opens up at the end of the sample. The hours gap has swung from very negative (in 1992) to firmly positive more recently.

The three panels of figure 2 show the log level of productivity and the estimated level of trend productivity for the 1970s, 1980s, and 1990s. The figure reiterates the point that it is only in recessions and the early stages of recoveries - when output is either falling sharply or growing very rapidly - that much of a gap opens up between actual and trend productivity. In particular, since 1995, there has been little deviation of productivity from its trend. Hence, according to this model, most of the recent increases in productivity have been increases in trend productivity.

Figure 3 shows the log of hours per person and its trend. Starting in the 1980s, there has been a steady increase in trend hours per person. In addition, in the early 1990s, there has been a strong increase in the cyclical component of hours per person. Figure 4 shows the model's estimate of trend productivity growth. The solid line in the figure is estimate of the trend productivity growth rate which takes advantage of all of the information in the sample. It is thus the best estimate, as of today, of trend productivity growth at each point in time; this estimate is referred to in the state-space literature as the "smoothed" trend estimator. According to this measure, trend productivity growth fell steadily from the early 1960s to the mid-1970s. Over the 1973to-1994 period, trend productivity growth by this measure stayed within 0.4 percentage point of an average of 1.6 percent, similar to conventional estimates of trend productivity 
growth over this period. Since the early 1990s, this measure of trend productivity growth has increased steadily, and as of the second quarter of 2000, was at 2.7 percent. $^{4}$

Figure 4 also shows an estimate of the productivity trend that is based only on information that precedes each period's estimate. As estimates of trend productivity growth based on knowledge available at the end of the sample, these estimates are inferior to the smoothed estimates. However, they are useful for giving an impression of real-time estimates of trend productivity growth using this method. (The read on realtime estimates is only impressionistic because estimates of the model's parameters are based on the entire sample. The sense in which this "backward" trend estimate do not take into account future data is that, conditional on the parameters of the model, it does not use future data in estimating the trend.) Interestingly, these estimates suggest that there have been a couple of "false dawns" of higher productivity growth since the early 1980s, first in 1985-86 and again during the "jobless recovery" of 1992, when this method might have suggested a pick-up in trend productivity growth. However, in neither of those earlier episodes did the estimate of trend productivity growth move above $2-1 / 2$ percent, as it has most recently.

Figure 5 compares smoothed estimates of trend productivity growth using two different estimates of the standard error of the change in trend productivity growth - the preferred estimate of 0.22 that was used in figure 4 and an estimate that uses a standard error of 0.57 , consistent with the upper end of the 90 percent confidence interval of the

4. As noted above, Brainard and Perry (1999) also use state-space techniques to estimate trend productivity growth. They also find an increase in trend productivity growth in the late 1990s. In particular, they estimate that by the end of 1998, trend productivity growth was 1.9 percent at an annual rate. By way of comparison, my estimates put trend productivity growth at the end of 1998 at 2.5 percent when subsequent data is taken advantage of, or 2.0 percent using only data available as of 1998:Q4. 
underlying test statistic (the parameter estimates of this model are shown in column 2 of table 2). Of course, the trend estimates based on the median of the distribution are to be preferred, but the estimate based on the larger standard error is of interest in giving some notion of the sensitivity of the estimates. As we would anticipate, this estimate of trend growth is more variable - for example, estimated trend productivity growth hit a deeper low-point at the beginning of the 1980s. As of the second quarter of 2000, trend productivity growth from the model assuming greater variation was 3-1/2 percent.

Figure 6 compares estimates of the smoothed productivity trend for models with and without a Phillips curve. For both models, the standard error of the change in trend productivity growth is 0.22 . Hence, the estimate for the model with the Phillips curve is the same as in figure 4; the parameter estimates for the model without the Phillips curve were presented in column 4 of table 2. As is clear from the figure, the estimates of the productivity trend growth are little affected by whether the Phillips curve is included in the model: The two estimates of trend productivity growth are within 0.1 percentage point of each other at all times. For the latest period plotted, the first quarter of 2000, the estimated trend growth rate from the model without the Phillips curve was slightly higher than from the model that includes the Phillips curve, although it still rounded to 2.7 percent.

\section{Estimation of Trend Multifactor Productivity}

As noted by Oliner and Sichel (2000), a considerable portion of the pick-up in productivity growth in recent years can be ascribed to greater rates of capital accumulation. In this section, I explore the implications of taking explicit account of observable sources of trend productivity growth such as capital accumulation and then 
using time-varying parameter techniques to model only the residual portion of labor productivity.

In particular, in this section, I modify the model presented in section 2 to allow capital accumulation-and changes in the quality of the workforce-to affect labor productivity. For these purposes, I take capital accumulation and labor quality to be exogenous. While the business cycle clearly affects business investment, it is reasonable to argue that the source of an additional unit of capital is irrelevant to its effect on productivity, so that ignoring the effects of the cycle on investment is unlikely to affect our estimates of the contribution of capital accumulation to productivity growth. A similar argument would apply to education decisions that are the major determinant of labor quality, although education is probably affected by the business cycle to a much smaller degree than is investment.

\section{6.a. Model with multifactor productivity}

The standard Cobb-Douglas production function is a useful point of departure for a model with multifactor productivity:

$$
Q_{t}=A_{t} K_{t}^{\prime \prime}\left(E_{t} H_{t}\right)^{(1-")},
$$

where $A$ is multifactor productivity growth, $K$ is the flow of capital services, $E$ is a measure of labor quality that reflects worker's educational attainment and experience, and " is the elasticity of output with respect to an additional unit of capital services Rearranging and taking logs, we have the following expression for the log of output per hour:

$$
\mathrm{B}_{t} / q_{t}-h_{t}=a_{t}+"\left(k_{t}-h_{t}\right)+(1-") e_{t} .
$$

Under the assumption that the service flows from physical and educational capital are given, the natural definition for "trend" productivity is: 


$$
\mathrm{B}_{t}^{*} / a_{t}^{*}+"\left(k_{t}-h_{t}^{*}\right)+(1-") e_{t}
$$

Because capital services and labor quality are observable, it is natural to apply timevarying parameter techniques only to trend multifactor productivity. (Trend hours were, of course, already part of the earlier model.):

$$
a_{t}^{*}=\left({ }_{t}+a_{t-1}{ }^{*}+, 2 t .\right.
$$

Here, ${ }_{2}$ is the shock to the level of trend multifactor productivity. In parallel with the specification for labor productivity, the drift term in trend multifactor productivity is itself assumed to be a time-varying parameter:

$$
C_{t}=C_{t-1}+\mathrm{L}_{t}
$$

The rest of the model remains as described in section 2: Trend hours are assumed to follow a random walk; trend output is the sum (in logs) of trend hours and trend labor productivity; the deviation of output from trend is assumed to follow a second-order autoregressive process; hours are assumed to follow a partial-adjustment process to close a productivity gap; and a Phillips curve may be added to the model to further separate trend and cycle.

\section{6.b. Estimates of the model with multifactor productivity}

To implement the model, I need data on capital services and labor quality. I use data based on the Bureau of Labor Statistics' multifactor productivity program. These data are annual and are, at this writing, available only through 1997. I extended them to 1999 using methods described in Oliner and Sichel (2000) and, as described in more detail in the data appendix, converted them to quarterly frequency using cubic spline interpolation.

A key parameter of the Cobb-Douglas production function is the elasticity of output with respect to capital, ". I use a value of 0.3147 for ", which is the average 
value of capital's share of income over the 1960 to 1999 period in the extended BLS multifactor productivity dataset. Under the assumption of perfect competition, capital's share of income should, on average, equal the output elasticity of capital.

As with labor productivity, I need estimates of the standard error of the change in trend multifactor productivity. Again, I estimated this in two ways, first from the raw multifactor productivity data and second from an estimate of trend multifactor productivity from a first-stage estimate of my model that sets the standard error of the change in trend productivity growth to zero. These estimates were 0.23 and 0.22 percentage point, respectively - close both to each other and to the point estimates for the standard error of the change in trend simple labor productivity growth. As with the estimates for trend labor productivity, the estimates were significantly different from zero at the 10 percent level, but not at the 5 percent level. The upper boundary of the 90 percent confidence interval for the estimate using the raw MFP data, which I use in my sensitivity analysis below, is 0.61 percentage point.

Column 5 of table 2 shows the estimates of the model under the assumption that the standard error of the change in trend multifactor productivity growth is 0.23 percentage point. The results are for the most part similar to those for the model with labor productivity. The main differences concern the hours-adjustment model: One is that the initial reaction of hours to a cyclical output shock is smaller than in the laborproductivity models. ${ }^{5}$ Another is that the standard error of the shock to the hoursadjustment model has been set equal to zero. As discussed earlier, the variance of this

5. Further testing, not shown in the table, indicated that the two restrictions imposed on the hours-adjustment model continue to hold in the multifactor productivity model. 
shock is often small and not statistically significant - and because it is not precisely estimated, including it can lead to convergence problems.

In other estimates, I experimented with different assumptions about the standard error of the change in the trend multifactor productivity growth rate. In particular, I reestimated the model assuming that the standard error was zero and that it was 0.61 percentage point, the upper end of the 90 percent confidence interval. I found that, as was the case for output per hour, these changes had very little effect on the other estimated parameters of the model. As a consequence, I have not reported these results, although I present the trend growth rate of multifactor productivity consistent with the higher estimate of the standard error in the next subsection.

\section{6.c. Implications of the model for trends in multifactor productivity}

Figure 7 presents the implications of the multifactor productivity model for estimates of trend productivity growth. The top panel shows the model's "smoothed" estimates of trend multifactor productivity growth. The overall contour of trend multifactor productivity growth is similar to that for simple labor productivity: There is a slowdown in productivity growth from a peak in the early 1960s to a low point in the late 1970s; productivity growth remained slow in the remainder of the 1980s and into the early 1990s, with an uptrend evident in the latter part of the 1990s. Of course, because capital accumulation and labor quality account for part of labor productivity growth, multifactor productivity growth is lower than overall labor productivity growth. Estimated MFP growth was 1-3/4 percent in the early 1960s; fell to less than $1 / 4$ percent in the early 1980 s; rebounded to about $1 / 2$ percent from the mid-1980s to the mid-1990s; and has moved up further in the second half of the 1990s, to 1.1 percent in the period from mid-1998 to the first half of 2000. The recent step-up in MFP 
growth is less marked than the pick-up in labor productivity growth from earlier figures, because of the role of greater capital accumulation in recent years.

The top panel of figure 7 also shows the "smoothed" productivity trend estimate for the model that uses the value of the standard error of the change in trend productivity associated with the upper end of the 90 percent confidence interval of the median estimate ( 0.61 percentage point). This estimate of trend growth is, as expected, more variable than the preferred estimate. It has the implausible implication that there was technical regress at the rate of about 0.5 percent per year in the 1979-to-1981 period. Of course, this estimate of the trend is inferior to the estimate based on the median estimate of the standard error of the change in trend growth, and is included simply as giving an indication of the sensitivity of the results to various assumptions.

The lower panel combines the estimated trend multifactor productivity growth rate with contributions from capital deepening and labor quality to form an estimate of trend labor productivity, according to the formula:

$$
) \mathrm{B}_{t}^{*} /\left({ }_{t}+"() k_{t}-\right) h_{t}^{*}\right)+(1-")\right) e_{t}
$$

The panel also shows the smoothed estimate of the trend labor productivity growth rate from figure 4, which is consistent with a standard error of the change in trend growth equal to 0.22 percentage point. One result that is immediately apparent is that the trend labor productivity growth rate built up from trend MFP growth has much more highfrequency volatility than the direct estimate. The reason is apparent from the formula above: The change in trend hours is used to normalize capital deepening, and changes in trend hours, despite abstracting from cyclical hours variation, can nonetheless be quite large from quarter to quarter. Still, cutting through the quarterly gyrations, the overall 
movements of trend productivity growth in the two measures are similar, with both series exhibiting the same general patterns of slowdown and recovery.

In the most recent period, the two measures are telling somewhat different stories; over the final eight quarters of the sample, from 1998:Q3 to 2000:Q2, a period when MFP growth was 1.1 percent at an annual rate, trend labor productivity growth built up from MFP growth has averaged 3.1 percent at an annual rate, $1 / 2$ percentage point higher than the direct estimate. Because the MFP-based measure takes direct account of the increase in capital accumulation, it is arguably a superior estimate of current trend productivity growth. ${ }^{6}$

\section{Conclusions}

In this paper, I develop a flexible way of estimating variations in the trend productivity growth rate using time-varying parameter techniques. Estimates from these models suggest that trend productivity growth has picked up in recent years. Using output per hour as the measure of productivity, the model's estimates suggest that trend productivity moved up more than a percentage point between the early 1990s and the second quarter of 2000 , to about $2-2 / 3$ percent at an annual rate. According to the logic of the model, in which last quarter's estimate of trend growth is the best forecast of this quarter's trend growth, this level of productivity growth can be expected to persist.

6. One reason for hesitation concerning the MFP-based estimates of trend productivity growth is that, historically, periods of rapid capital accumulation have not been systematically associated with periods of rapid labor productivity growth. An example is the late 1970s, when capital services growth was relatively high but labor productivity growth was low. The combined effects manifest themselves in figure 7 as a very low pace of trend MFP growth in the late 1970s. Still, for the most recent period, capital accumulation seems a plausible explanation for faster productivity growth and thus worth putting some weight on, even if past episodes may give us some pause in fully embracing the MFP-based estimates. 
However, capital accumulation has picked up considerably in recent years, and it seems sensible to consider a model that explicitly allows capital accumulation to affect labor productivity growth. When the model is extended to include capital accumulation, it suggests that trend productivity growth has been about 3 percent at an annual rate in the past couple of years. The model predicts that if capital accumulation remains at recent levels, trend productivity growth can be expected to remain around 3 percent. 


\section{Data appendix}

\section{A. Data on capital services and labor quality.}

Capital services. The data through 1997 are based on the BLS multifactor productivity dataset, with the following modifications: First, an estimate of service flows from software is added, using recently available national accounts data on software investment. Second, an alternative capital series for personal computers is used that has a service life consistent with the latest national accounts data. Data are extended to 1999 using disaggregated investment data from the national accounts. See Oliner and Sichel (2000) for more details on the procedures used to construct the annual data. Quarterly data are cubic spline interpolations of the annual data; to infer capital services for 2000:Q1 and Q2, it was assumed that investment in the second half of 2000 would continue at the first half level.

Labor quality. Through 1997, quarterly data on the contribution of labor quality to output growth is a cubic spline interpolation of annual labor quality contributions from the BLS multifactor productivity dataset. For 1998 and beyond, the contribution of labor quality to output growth is assumed to be 0.3 percentage point at an annual rate, near its average level for the 1990-to-1997 period.

\section{B. Data used in the Phillips curve.}

Relative prices of food, energy, and imports. The relative prices of food and energy are the chain-type price indexes for the relevant component of personal consumption expenditures divided by the lagged level of the chain-type price index for personal consumption expenditures other than food and energy. From 1969:Q3 to 2000:Q1, the relative price of imports is a chain-type price index for merchandise imports other than petroleum, computers, and semiconductors, divided by the lagged level of the chaintype price index for consumer expenditures other than food and energy. For the period from 1967:Q1 to 1969:Q2, the numerator of the import price variable is a price index for merchandise imports excluding petroleum; for the period before 1967:Q1, the numerator is the price index for total imports excluding petroleum. The import price index is based on national accounts data, except for the adjustment for semiconductors, which makes use of unpublished data from the Bureau of Economic Analysis. The relative price variables enter the model as a percent change at an annual rate.

Wage and price control dummy. This variable is equal to one in each of the eleven quarters from 1970:Q3 to 1975:Q1 and is equal to $-11 / 3$ in the three quarters from 1975:Q2 to 1975:Q4. 
Table 1

Estimates of the State-Space Model of Hours and Output with Fixed Trend Productivity Growth

1960:Q4 to 2000:Q2

\begin{tabular}{|c|c|c|c|c|c|}
\hline & (1) & (2) & (3) & (4) & (5) \\
\hline \multicolumn{6}{|l|}{ Trend parameters } \\
\hline Standard error of shock to & .52 & .48 & .48 & .49 & .50 \\
\hline hours trend & $(.04)$ & $(.07)$ & $(.07)$ & $(.08)$ & $(.07)$ \\
\hline Standard error of shocks to & .73 & .74 & .74 & .75 & .74 \\
\hline productivity trend level & $(.07)$ & $(.08)$ & $(.08)$ & $(.07)$ & $(.08)$ \\
\hline \multirow[t]{2}{*}{ Hours drift (annual rate) } & .21 & .21 & .21 & .21 & .21 \\
\hline & (.19) & $(.18)$ & $(.18)$ & $(.18)$ & (.19) \\
\hline \multirow{2}{*}{$\begin{array}{l}\text { Productivity drift (annual } \\
\text { rate) }\end{array}$} & 2.09 & 2.10 & 2.10 & 2.09 & 2.10 \\
\hline & $(.25)$ & $(.25)$ & $(.24)$ & $(.25)$ & $(.25)$ \\
\hline \multicolumn{6}{|l|}{ Cyclical parameters } \\
\hline \multirow[t]{2}{*}{ Output gap, t-1 } & 1.65 & 1.61 & 1.60 & 1.80 & 1.62 \\
\hline & $(.11)$ & $(.12)$ & $(.12)$ & $(.32)$ & (.12) \\
\hline \multirow[t]{2}{*}{ Output gap, t-2 } & -.71 & -.67 & -.67 & -.91 & -.69 \\
\hline & $(.11)$ & $(.12)$ & $(.12)$ & $(.36)$ & (.12) \\
\hline \multirow[t]{2}{*}{ Hours gap, t-1 } & -- & -- & -- & -.13 & -- \\
\hline & & & & $(.28)$ & \\
\hline \multirow[t]{2}{*}{ Hours gap, $\mathrm{t}-2$} & -- & -- & -- & .19 & -- \\
\hline & & & & $(.30)$ & \\
\hline \multirow[t]{2}{*}{ Standard error } & .59 & .64 & .63 & .56 & .61 \\
\hline & $(.14)$ & $(.17)$ & $(.15)$ & $(.19)$ & (.16) \\
\hline \multicolumn{6}{|l|}{ Hours model } \\
\hline \multirow[t]{2}{*}{ Current output gap } & .32 & .46 & .46 & .42 & .43 \\
\hline & (.13) & $(.06)$ & $(.06)$ & $(.07)$ & $(.06)$ \\
\hline \multirow[t]{2}{*}{ Lagged output gap } & .25 & -.01 & $.00^{*}$ & $.00 *$ & $.00^{*}$ \\
\hline & $(.21)$ & $(.02)$ & -- & -- & -- \\
\hline \multirow[t]{2}{*}{ Lagged hours gap } & .37 & $.55^{*}$ & $.54 *$ & $.58 *$ & $.57 *$ \\
\hline & $(.17)$ & -- & -- & -- & -- \\
\hline \multirow[t]{2}{*}{ Standard error } & .00 & .12 & .11 & .11 & .10 \\
\hline & -- & (.13) & (.13) & $(.15)$ & (.15) \\
\hline \multicolumn{6}{|l|}{ Phillips curve } \\
\hline \multirow[t]{2}{*}{ Output gap } & .072 & .072 & .073 & .070 & -.065 \\
\hline & $(.028)$ & $(.028)$ & $(.028)$ & $(.028)$ & $(.080)$ \\
\hline Hours gap & -- & -- & -- & -- & .165 \\
\hline \multirow{2}{*}{ Relative import prices } & .035 & .035 & .035 & .035 & $\begin{array}{c}(.088) \\
.038\end{array}$ \\
\hline & (.009) & (.009) & (.009) & (.009) & (.009) \\
\hline \multirow[t]{2}{*}{ Relative food prices } & .031 & .030 & .030 & .030 & .027 \\
\hline & $(.007)$ & (.007) & $(.007)$ & $(.007)$ & $(.007)$ \\
\hline \multirow[t]{2}{*}{ Standard error } & .65 & .66 & .66 & .66 & .65 \\
\hline & $(.04)$ & $(.04)$ & $(.04)$ & $(.04)$ & $(.04)$ \\
\hline \multicolumn{6}{|l|}{ Summary statistics } \\
\hline Log likelihood & -75.3 & -75.9 & -75.9 & -75.6 & -74.7 \\
\hline
\end{tabular}

* Constrained parameter. 
Table 2

Estimates of the State-Space Model of Hours and Output with Time-varying Trend Productivity Growth

1960:Q4 to 2000:Q2

\begin{tabular}{|c|c|c|c|c|c|}
\hline & (1) & (2) & (3) & (4) & (5) \\
\hline Measure of productivity & \multicolumn{4}{|c|}{ Output per hour } & Multifactor \\
\hline \multicolumn{6}{|l|}{ Trend parameters } \\
\hline $\begin{array}{l}\text { Standard error of change in trend } \\
\text { productivity growth rate } \\
\text { (annual rate) }\end{array}$ & $.22 *$ & $.57 *$ & $.0 *$ & $.22 *$ & $.23^{*}$ \\
\hline Standard error of shocks to & .46 & .46 & .48 & $\begin{array}{l}.41 \\
(09)\end{array}$ & .51 \\
\hline $\begin{array}{l}\text { Standard error of shocks to level } \\
\text { of productivity trend }\end{array}$ & $\begin{array}{l}.69 \\
(08)\end{array}$ & $\begin{array}{l}.70 \\
(08)\end{array}$ & $\begin{array}{l}.74 \\
(08)\end{array}$ & $\begin{array}{l}.65 \\
(09)\end{array}$ & $\begin{array}{l}.68 \\
(09)\end{array}$ \\
\hline Hours drift (annual rate) & $\begin{array}{l}.21 \\
(.18)\end{array}$ & $\begin{array}{l}.20 \\
(.18)\end{array}$ & $\begin{array}{l}.21 \\
(.18)\end{array}$ & $\begin{array}{l}.12 \\
(.17)\end{array}$ & $\begin{array}{l}.19 \\
(.18)\end{array}$ \\
\hline \multicolumn{6}{|l|}{ Cyclical parameters } \\
\hline Output gap, t-1 & $\begin{array}{l}1.58 \\
(.12)\end{array}$ & $\begin{array}{l}1.58 \\
(.11)\end{array}$ & $\begin{array}{l}1.60 \\
(.12)\end{array}$ & $\begin{array}{l}1.53 \\
(.12)\end{array}$ & $\begin{array}{l}1.54 \\
(.10)\end{array}$ \\
\hline Output gap, t-2 & -.64 & -.64 & -.67 & -.57 & -.61 \\
\hline Standard error & $\begin{array}{l}(.12) \\
.67 \\
(.15)\end{array}$ & $\begin{array}{l}(.11) \\
.66 \\
(.15)\end{array}$ & $\begin{array}{l}(.12) \\
.63 \\
(.15)\end{array}$ & $\begin{array}{l}(.13) \\
.77 \\
(.15)\end{array}$ & $\begin{array}{l}(.11) \\
.73 \\
(.13)\end{array}$ \\
\hline \multicolumn{6}{|l|}{ Hours model } \\
\hline Current output gap & $\begin{array}{c}.45 \\
(.06)\end{array}$ & $\begin{array}{c}.47 \\
(.07)\end{array}$ & $\begin{array}{c}.46 \\
(.06)\end{array}$ & $\begin{array}{c}.45 \\
(.05)\end{array}$ & $\begin{array}{c}.38 \\
(.03)\end{array}$ \\
\hline Lagged output gap & $\begin{array}{l}.00 * \\
--\end{array}$ & $\begin{array}{l}.00^{*} \\
--\end{array}$ & $\begin{array}{l}.00 * \\
--\end{array}$ & $\begin{array}{l}.00^{*} \\
--\end{array}$ & $.00^{*}$ \\
\hline Lagged hours gap & $.55^{*}$ & $.53^{*}$ & $.54 *$ & $.55^{*}$ & $.62^{*}$ \\
\hline Standard error & $\begin{array}{l}.15 \\
(.10)\end{array}$ & $\begin{array}{l}.14 \\
(.10)\end{array}$ & $\begin{array}{l}.11 \\
(.13)\end{array}$ & $\begin{array}{l}.21 \\
(.07)\end{array}$ & $.00 *$ \\
\hline \multicolumn{6}{|l|}{ Phillips curve } \\
\hline Output gap & $\begin{array}{c}.071 \\
(.028)\end{array}$ & $\begin{array}{c}.072 \\
(.028)\end{array}$ & $\begin{array}{c}.073 \\
(.028)\end{array}$ & -- & $\begin{array}{c}.062 \\
(.024)\end{array}$ \\
\hline Relative import prices & $\begin{array}{c}.035 \\
(.009)\end{array}$ & $\begin{array}{c}.036 \\
(.009)\end{array}$ & $\begin{array}{c}.035 \\
(.009)\end{array}$ & & $\begin{array}{l}.035 \\
(.009)\end{array}$ \\
\hline Relative food prices & $\begin{array}{l}.031 \\
(.007)\end{array}$ & $\begin{array}{l}.030 \\
(.007)\end{array}$ & $\begin{array}{l}.030 \\
(.007)\end{array}$ & & $\begin{array}{l}.032 \\
(.007)\end{array}$ \\
\hline Standard error & $\begin{array}{c}.66 \\
(.04)\end{array}$ & $\begin{array}{l}.66 \\
(.04)\end{array}$ & $\begin{array}{l}.66 \\
(.04)\end{array}$ & & $\begin{array}{c}.66 \\
(.04)\end{array}$ \\
\hline
\end{tabular}

* Constrained parameter.

Note: $\quad$ The log likelihood of the models is not reported because the median unbiased estimator upon which the estimates of the standard error of the change in trend productivity growth are based does not maximize the likelihood. 
Figure 1: Estimates of Hours Gap and Productivity Gap from State-Space Model

Percent deviation from trend

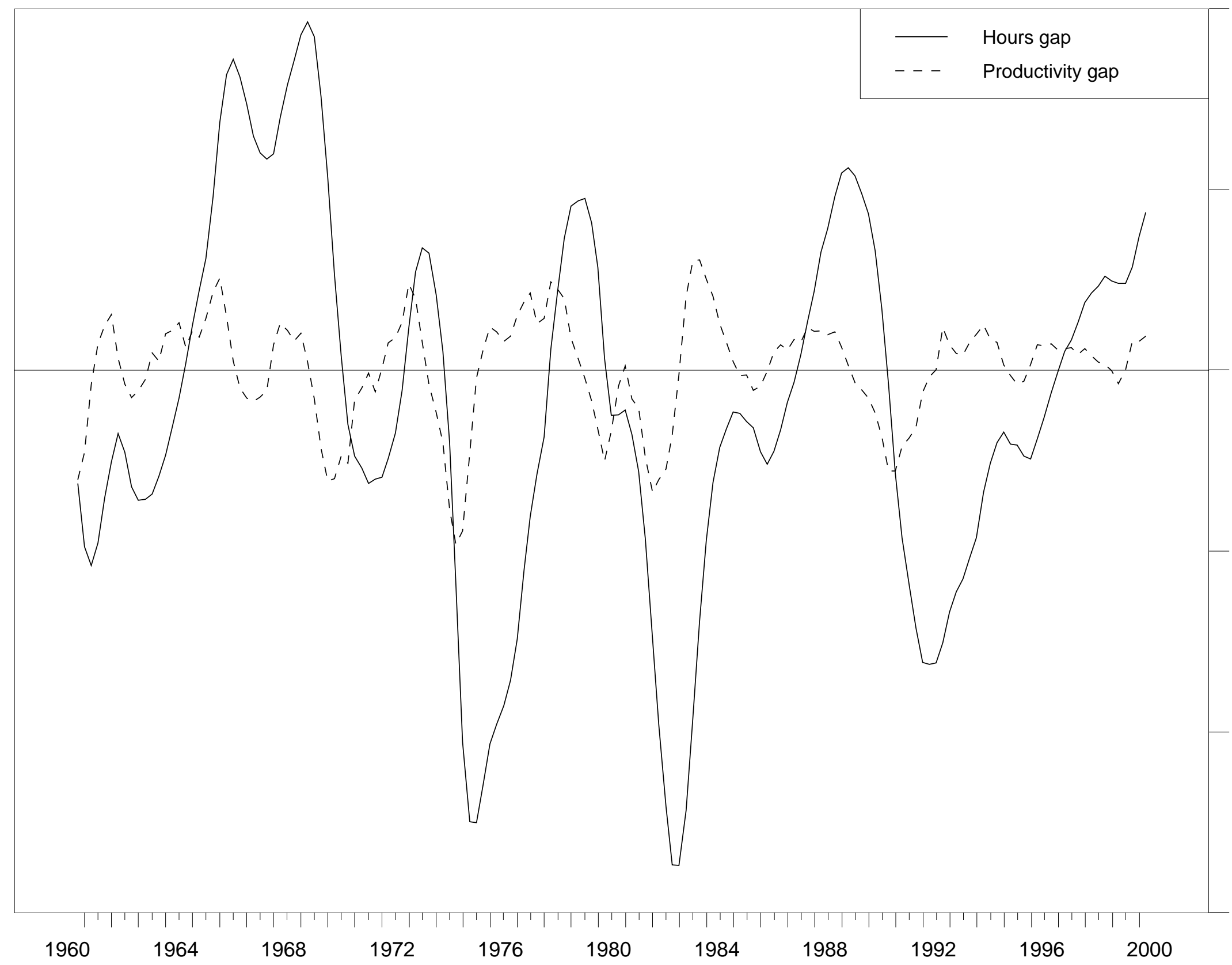


Figure 2: Productivity and Trend, by Decade

100 times log, rebased to $1990=0$

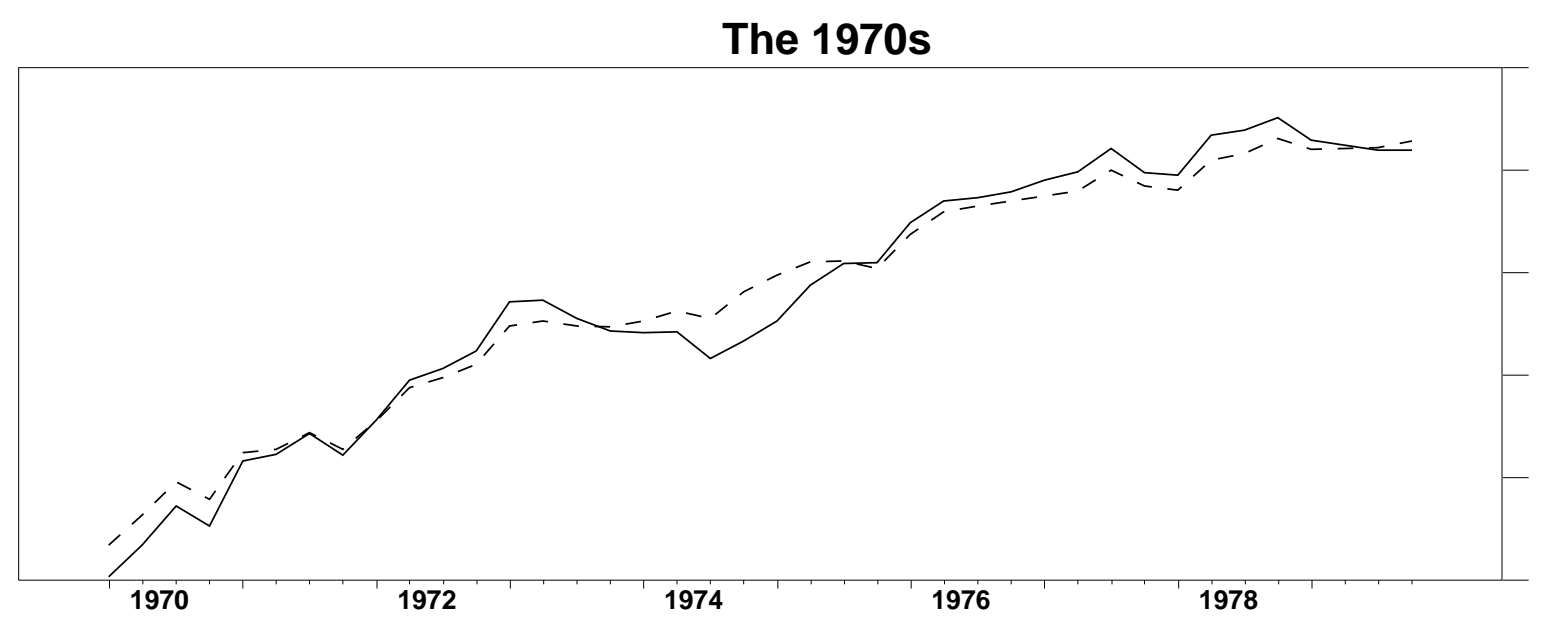

$-20$

$-25$

$-30$

$-35$

The 1980s

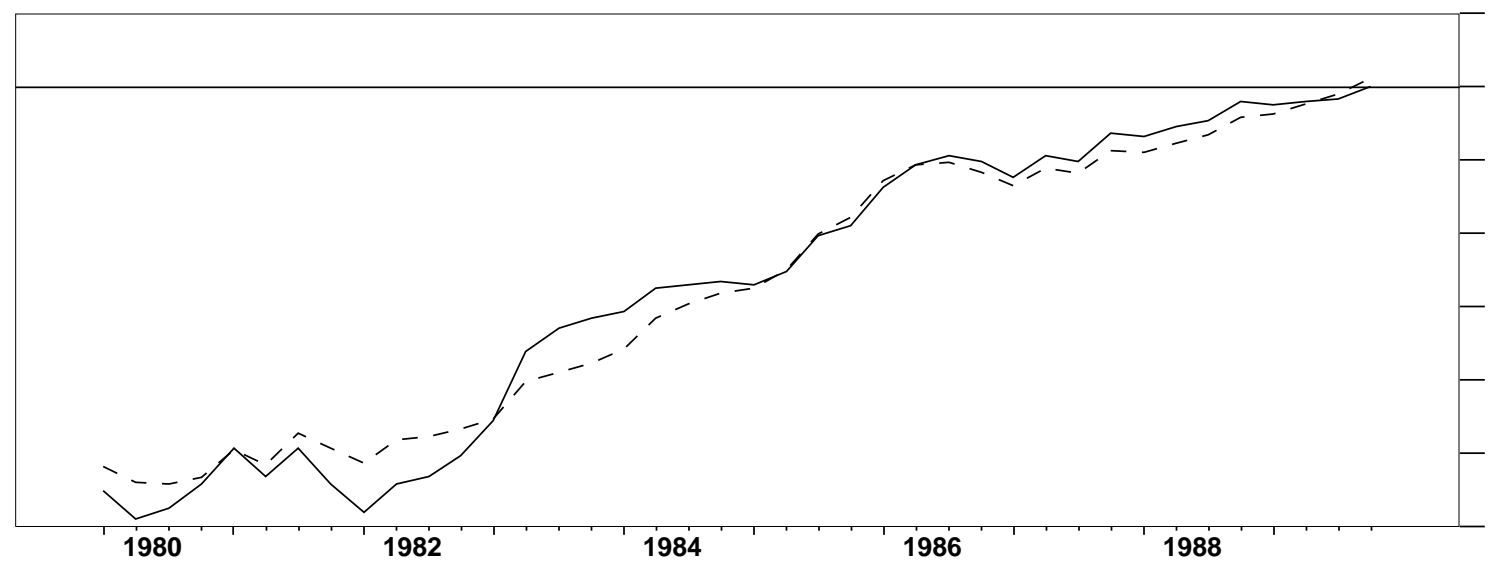

The 1990s

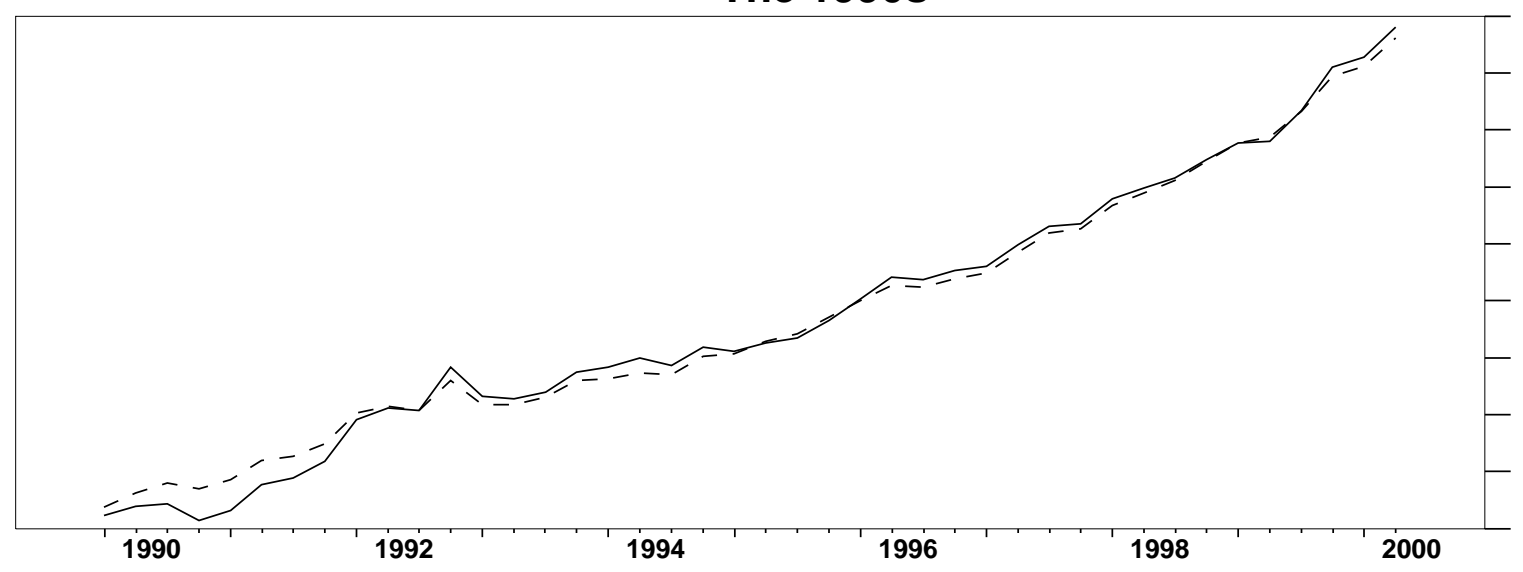

22.5

20.0

17.5

15.0

12.5

10.0

7.5

5.0

2.5 0.0

Productivity is the solid line; trend is dashed. 
Figure 3: Hours per Person and Trend

100 times log, deviations from mean

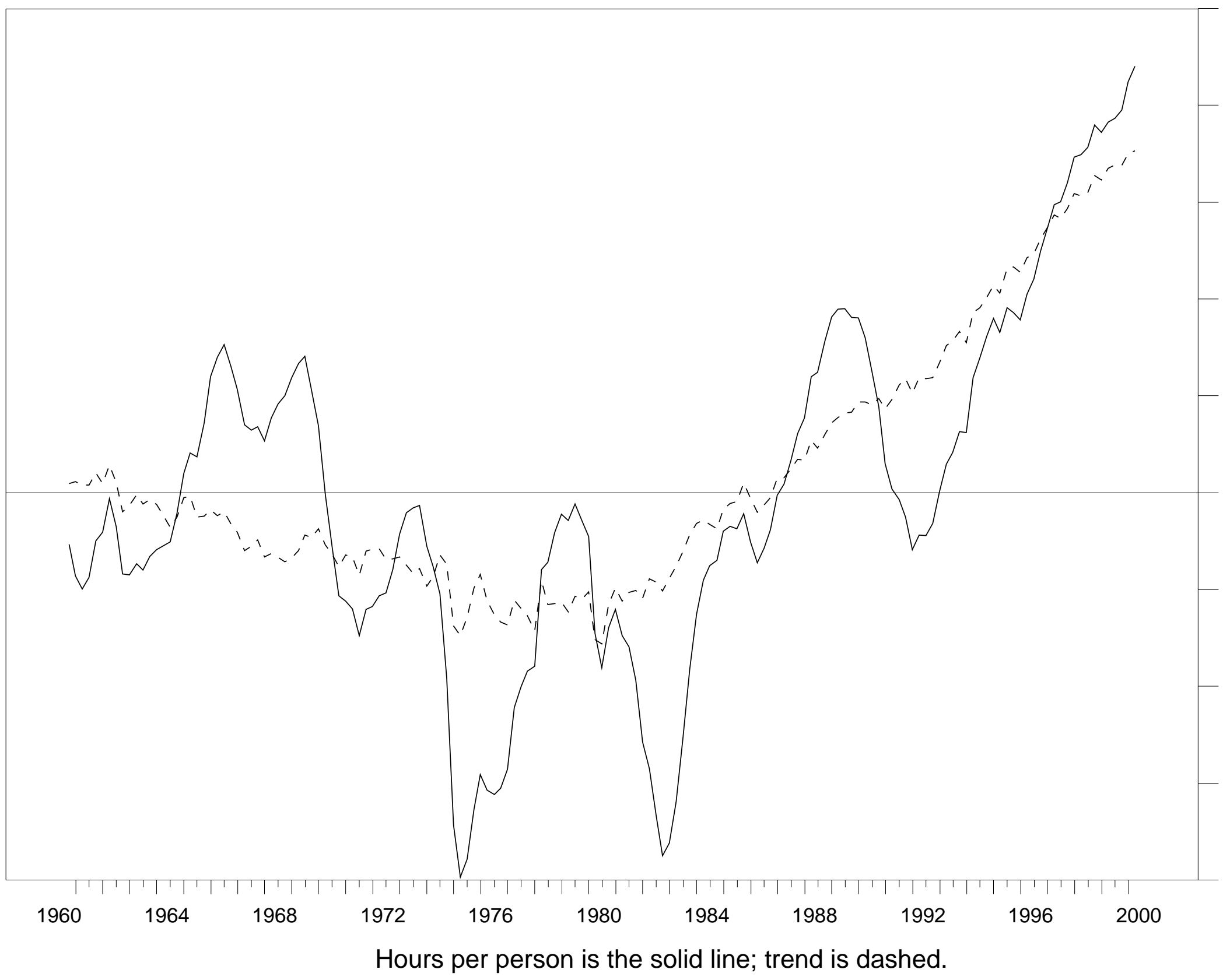

12.5

10.0

Hours per person is the solid line; trend is dashed. 
Figure 4: Model Estimates of Trend Productivity Growth

Percent change, annual rate

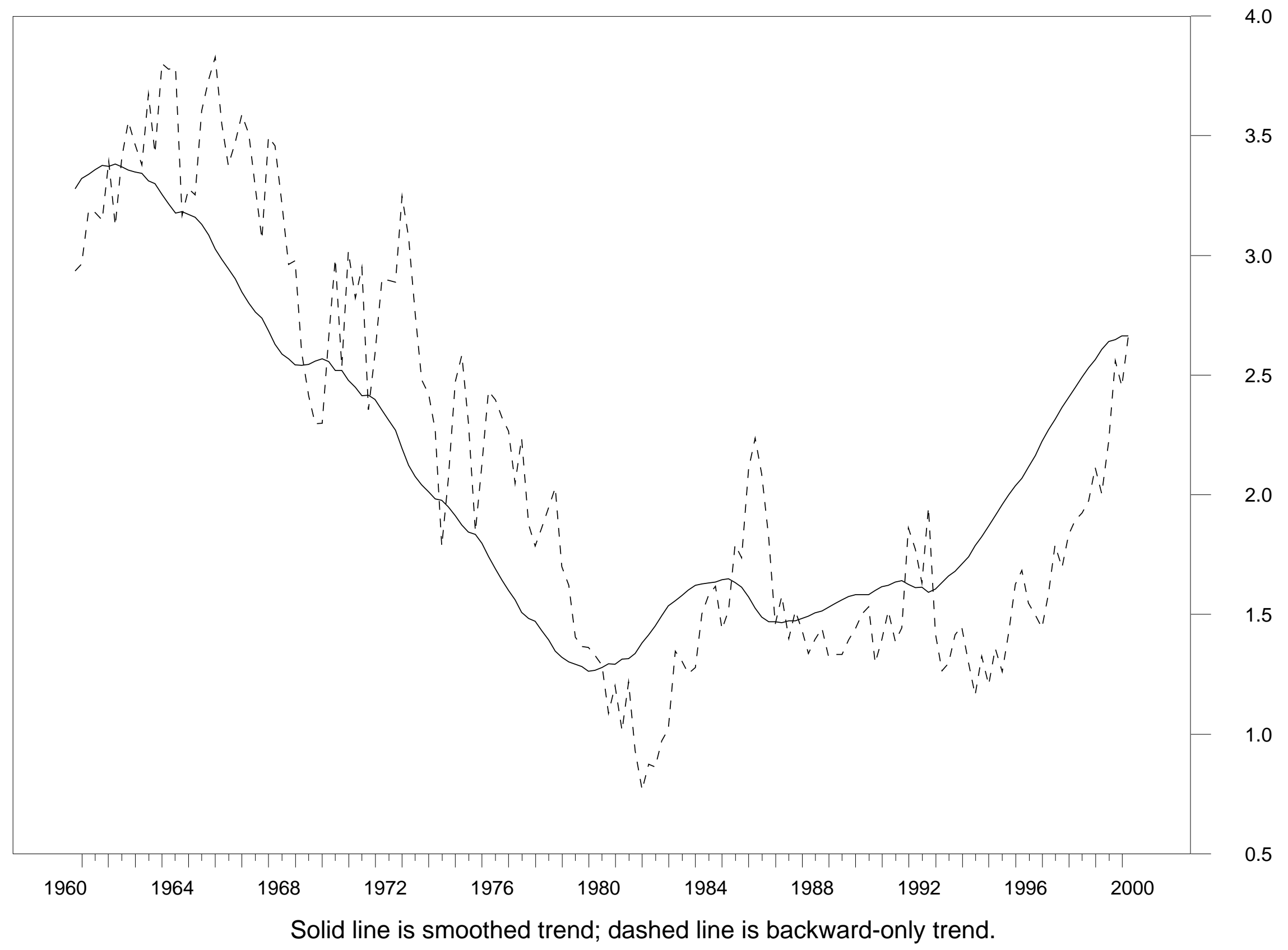


Figure 5: Comparison of Trend Productivity Growth Rates

Percent change, annual rate

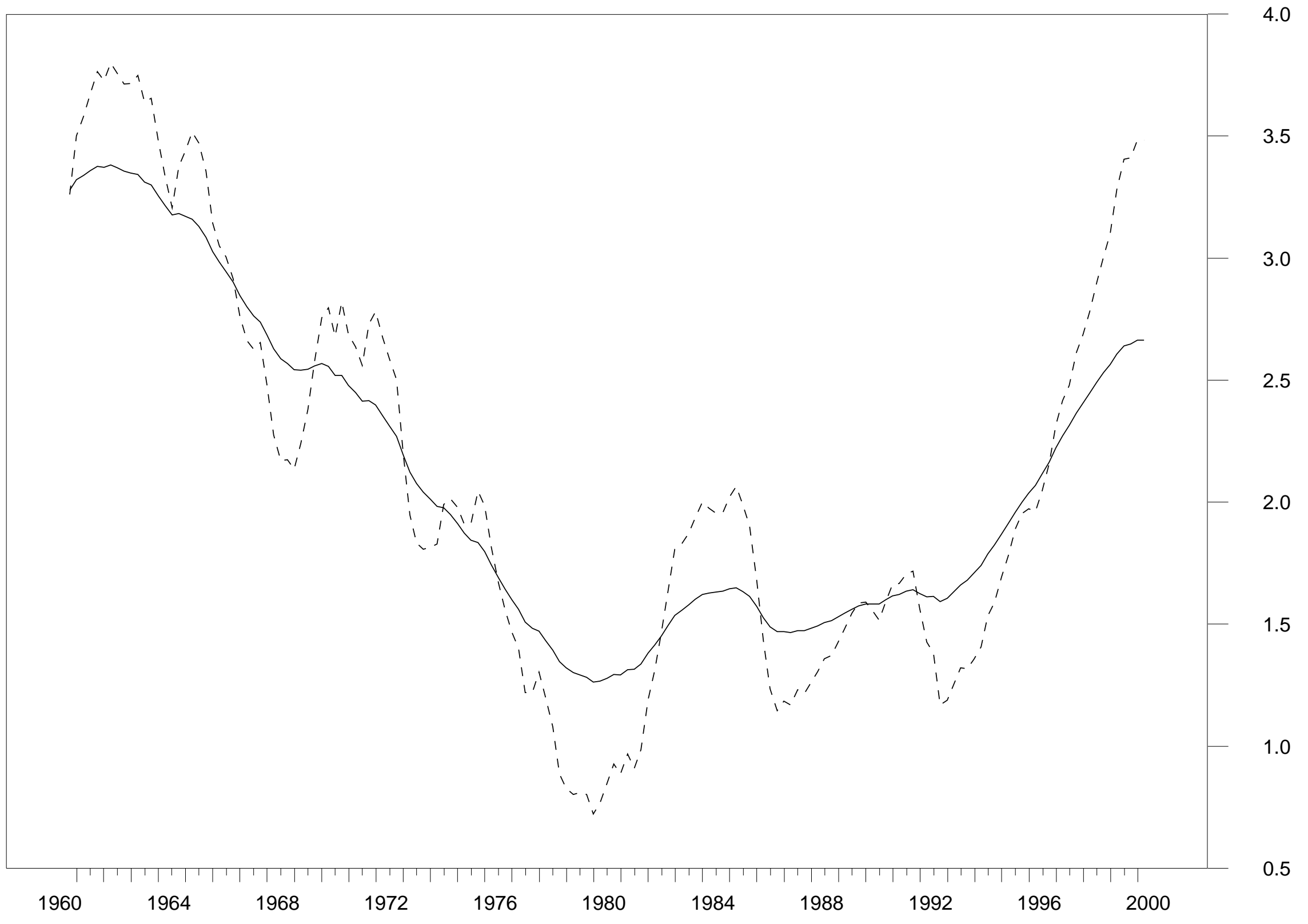

Solid line uses median variance estimate; dashed line uses variance for upper bound of 90 percent $\mathrm{Cl}$. 
Figure 6: Trend Productivity Growth Rates, Models with and without Phillips curves

Percent change, annual rate; both models use median variance estimate.

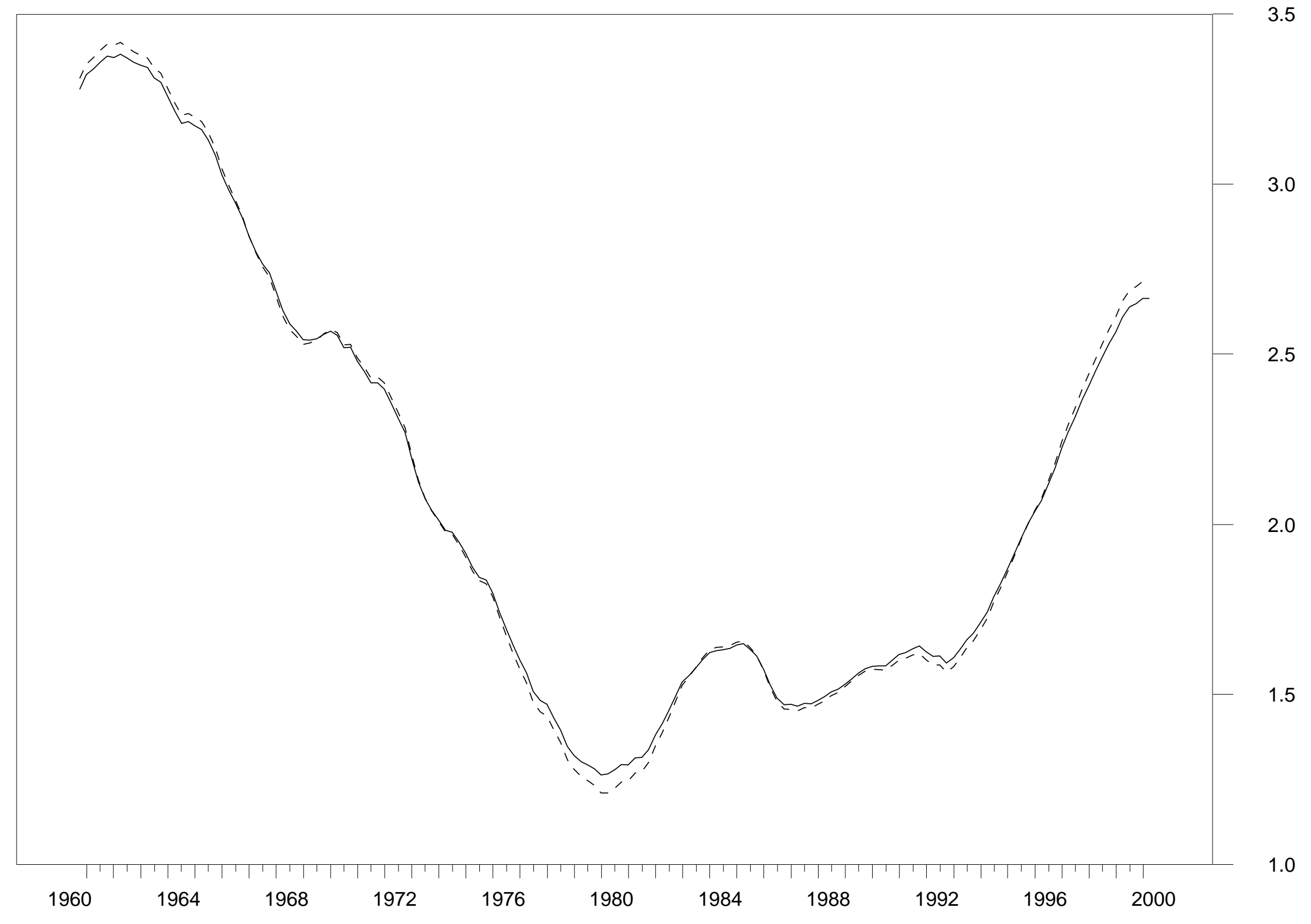

Solid line is from model with Phillips curve; dashed line is from model without Phillips curve. 


\section{Figure 7}

\section{Multifactor Productivity Growth, Estimates from State-Space Model}

Percent change, annual rate

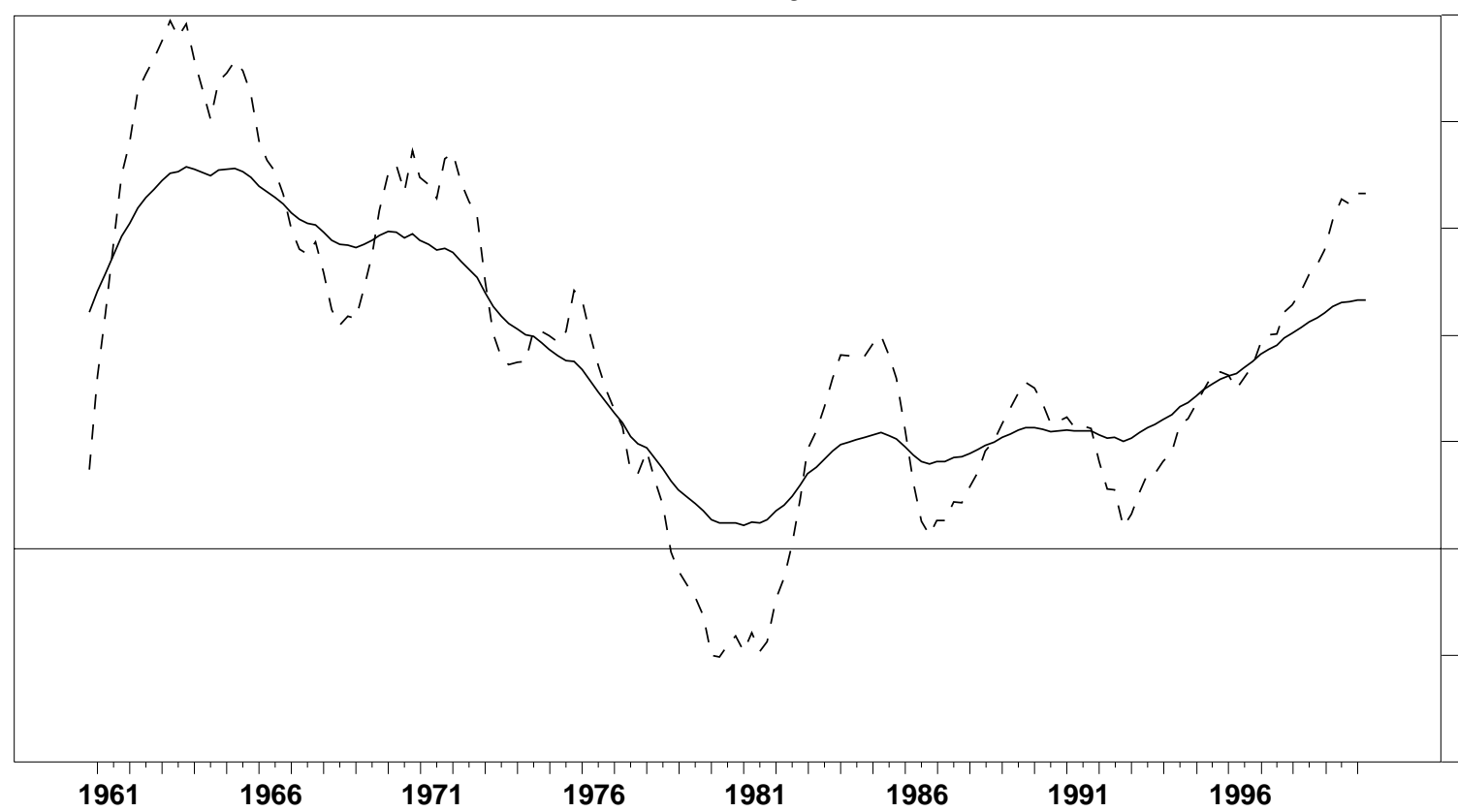

Solid line uses median variance estimate; dashed line uses upper bound of 90 percent $\mathrm{Cl}$.

\section{Labor Productivity Growth Based on MFP Growth}

Percent change, annual rate

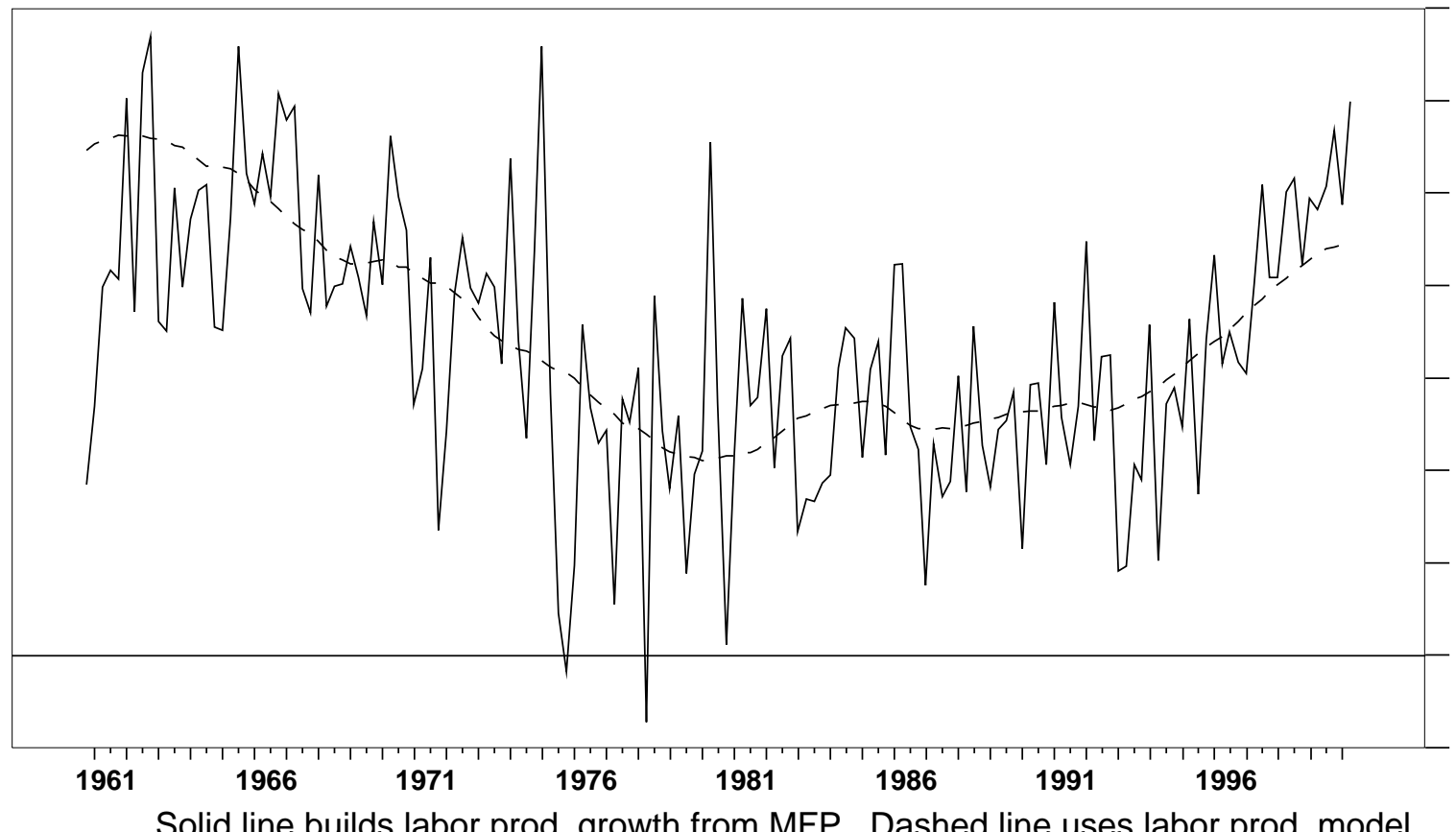

Solid line builds labor prod. growth from MFP. Dashed line uses labor prod. model. 


\section{References}

Brainard, William C., and George L. Perry (1999) "Making Policy in a Changing World," paper prepared for Yale-Brookings conference, Economic Events, Ideas, and Policies: The 1960s and After, November 12 and 13, 1999.

Braun, Steven N. (1990) "Estimation of Current-Quarter GNP by Pooling Preliminary Labor-Market Data,” Journal of Business and Economic Statistics 8, 293-304.

Clark, Peter K. (1987) “The Cyclical Component of U.S. Economic Activity,” Quarterly Journal of Economics 102, 797-814.

Kuttner, Kenneth N. (1994) "Estimating Potential Output as a Latent Variable," Journal of Business and Economic Statistics 12, 361-8.

Oliner, Stephen D., and Daniel E. Sichel (2000) "The Resurgence of Growth in the Late 1990s: Is Information Technology the Story?" Federal Reserve Board FEDS working paper no. 2000-20 (May).

Stock, James H., and Mark W. Watson (1998) "Median Unbiased Estimation of Coefficient Variance in a Time-Varying Parameter Model," Journal of the American Statistical Association 93, 349-58.

Watson, Mark W. (1986) "Univariate Detrending Methods with Stochastic Trends," Journal of Monetary Economics 18, 49-75. 